\title{
THE EFFECT OF COMPUTER-ENHANCED LEARNING THROUGH THE USE OF ASYNCHRONOUS DISCUSSION ON IMPROVING WRITING AND STUDENT PERCEPTION OF TECHNOLOGY-MEDIATED ENVIRONMENT
}

\author{
By \\ Dr. Waleed Ibrahim
}

Associate Professor

Research gournal Specific Fducation

Faculty of Specific Education

Mansoura University

ISSUE NO. 21, APRIL. 2011

مجلة بحوث التربية النوعية - جامعة المنصورة

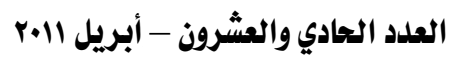




\title{
THE EFFECT OF COMPUTER-ENHANCED LEARNING THROUGH THE USE OF ASYNCHRONOUS DISCUSSION ON IMPROVING WRITING AND STUDENT PERCEPTION OF TECHNOLOGY- MEDIATED ENVIRONMENT
}

\author{
By \\ Dr. Waleed Ibrahim
}

\section{Abstract}

This study dealt with the effect of computer - mediated instruction on improving Arabic language writing skills of university juniors in Arabic language classes. It also surveyed data concerning student perceptions about the technology - enhanced environment of learning. Objectives of the study were to determine: a) the effect of technology - enhanced instruction on developing students writing and communication skills. B) The effects of technology on student perceptions in language learning environment. C) Draw conclusions concerning online design.

Computer - enhanced instruction and learning had a significant positive effect on improving learners' writing and communication skills. Students attributed important roles to instructor's plans. Independent learning skills were also enhanced. Implications for online design and other types of technology enhanced learning and teaching were presented. 


\title{
The effect of computer-enhanced learning through the use of Asynchronous discussion \\ THE EFFECT OF COMPUTER-ENHANCED LEARNING THROUGH THE USE OF ASYNCHRONOUS DISCUSSION ON IMPROVING WRITING AND STUDENT PERCEPTION OF TECHNOLOGY- MEDIATED ENVIRONMENT
}

\author{
By \\ Dr. Waleed Ibrahim
}

\section{Introduction :}

Recently the role of the teacher has changed from a conveyor of knowledge to a facilitator, a coach and a trainer who trains learners to develop a large number of cognitive, intellectual and affective skills. To do this, learners need to use technology - mediated instruction. In view of this, the learning theory of constructivism has been proposed as a basis for instruction (lebow, 1993) and as a viable theory of language instruction (Brooks \& Brooks, 1993, Blyth 1997). This theory acknowledges that students are not passive recipients of knowledge, but are active actors who are learning by engaging in the search for knowledge and participating in the construction of new idea(s) and meaningful experience (Lawry 2004 \& 2006). According to this theory, students are put on the right track for becoming independent learners by assuming responsibility for their own learning experience with the teacher as a facilitator rather then a purveyor of knowledge.

Furthermore, whole language pedagogy has recently formed the basis for strategies in language instruction (Shrum \& Glisan, 2000). Such a philosophy of whole language pedagogy rejects the fragmentation of language skills that views language acquisition as a set of hierarchically ordered sub-skills.

The instruction design of composition classes adopted in the study incorporated a constructivist and a whole language view. Hence, it has made use of interactive activities to train learners in Arabic composition such as the use of lab activities, authentic texts to create opportunities for students to use the language as a vehicle for exchanging information and by encouraging them to solve problems by providing links to online resources. 
The present study is consistent with the new trends of using technology in teaching and learning (and with the focus of educationalists and technologists on) the use of synchronous discussions, asynchronous discussions, computer labs, virtual classrooms, audio - conferencing, videoconferencing and phone conferencing as well as different types of web - based instruction focused on by education lists and technologists alike.

Studies on the effect of technology - based teaching and learning on student achievement, and studies related to student attitudes toward learning with technology are increasingly being reported (Salaberry, 2001). However,studies that have examined student perception after having gone through the experience of technology - enhanced learning, have been rather rare (Beauvois 1996, 1998, Cononleos \& Olive 1993; Warschaver, 1996). This paper reports on a descriptive study of female students' perception of the use of computer - mediated learning. More specifically it reports on the perceptions of university students enrolled in first year Arabic language classes at Princess Nora University in Riyadh during the academic year 1430 - 1431 AH i.e 2009 / 2010 AD. These classes used task - based internet activities and threaded asynchronous discussions via e-mail.

\section{Significance of the study:}

Theorizing on technology - based curriculum design derivesimportance party from actual experience of learners who can be labeled, ("knowledge navigators. " Syllabuses of faculties of education rarely concentrate on multimedia instruction to the extent that there is no single subject matter design that serves this purpose. In spite of this a large number of positive effects for students due to the use of technology have been reported in foreign research literature. It has been reported that technology - enhanced learning increases learners' motivation, self confidence, involvement in learning and leads to mastery of basic skills. More importantly it is more oriented towards learner - centered learning and interactivity (Dwyer, 1996; McGrath, 1998). Some studies (Nowaczyk, 1998) proved that it is more beneficial specifically for low achievers because it helps them become independent learners.

Moreover, the use of technology in language learning seems to influence language skills positively as it helps develop skills such as listening, speaking, reading and writing. Connelos \& Olvie, 1993; Warschauer, 1996 \& Beauvois, 1998) reported an improvement in student 
writing skills through the use of networked computers. According to Beauvis (1998) the move away from a teacher dominated class to a more free environment, where students are responsible for their own learning, resulted in an increase in both quantity and quality of expression. This improvement is not only limited to writing but embraces other skills as well. In a previous study by Beauvois (1994), 43 percent of the study sample reported an improvement in readingand as reported in the follow - up interviews, many students confirmed that they gained more confidence in speaking. Beauvois interpreted this finding by indicating that the increased amount of the language used in the technology - based environment is what helped them gain confidence and develop automatic structures that assist with their speaking skills and help make them become more fluent.

Thus the results of related studies in this domain stressed the need of using technology - based learning. The new challenge as (Wilson, 2000) stresses is to introduce learning programs while assuming that all learners can work and think independently and competitively with others, and that is a basic outcome that we endeavour to achieve.

In this context the present study derives its significance from training learners to learn independently and work interactively in a technology - based environment. This shift in focus extends to instruction and learning beyond the classroom and helps learners view these technologies as a means for negotiating meaning, collaboration and interaction. Instead of conveying language knowledge traditionally and formally to their learners, teachers become active participants but in a different way: they participate in facilitating communication and learning by offering a scaffold for their students(') learning.

\section{Objectives:}

\section{The present study aimed at:}

1. Creating opportunities through authentic computer - mediated task based activities for students to use language as a means of communication and exchanging information.

2. Evaluating students performance on the previous activities by getting to know their reflections on the experience as well as by testing the learnt material.

3. Using the interactive computer - mediated activities to enrich the syllabus in a holistic way rather than focusing on individual skills. 
4. Collecting data pertaining to learners' perceptions of language learning via asynchronous language learning computer - mediated activities.

5. Using the previous data to gain more insight into online curriculum design.

\section{Delimitations:}

The study is limited to students enrolled in the Arabic department at Princess Nora University for Girls in Riyadh during the academic year $1430-1431 \mathrm{AH}$. The study activities were administered during the first term.

\section{Methodology:}

Two research methodologies were used in the present research: the descriptive analytical approach to gather information related to the students' perceptions, and the experimental approach of pre/post- control group design to determine the effect of using the computer - enhanced activities on improving students' writing and survey their perceptions toward computer - based environment .

\section{The Problem:}

The study is an attempt to determine the effects of the use of computer - mediated activities on student success in writing and improvement in their communication skills. It also analyses student perceptions and attitudes toward technology - enhanced learning. It seeks answers to the following questions:

1. What is the experimental effect of the computer - mediated and online activities on improving students' writing skills?

2. What is technology's perceived effect on the learning of subject matter and linguistic skills?

3. Did learners perceive that they gained self- confidence as learners and/or increased their motivation due to the new experience?

4. Did learners enjoy the activities and experience?

5. What are the implications of the activities on informing future online curriculum design? 


\section{Review of Related studies:}

A large number of studies were conducted to determine and survey student perceptions and attitudes about technology - enhanced activities and their effects on improving their linguistic skills. Another type of research concentrated on measuring the experimental effect of this technology based teaching on improving the different language skills. In what follows, the researcher presents both types of previous studies i.e. survey studies and experimental studies .

\section{Survey Studies:}

In a study by Warshcauer (1996) entitled "motivational aspects of using computer for writing and communication" the researcher reached the conclusion that there are three main factors behind student motivation provided by technology: communication, empowerment and learning. "Communication" was manifested in the students' interest in the new experience, as they enjoyed engaging with other learners in authentic exchanges as opposed to contrived formal communicative situation controlled by the teacher. "Empowerment is shown by the finding that student's felt increased ability in the technology environment as they felt less isolated and less constrained and managed to break the ice of their fear of communication. The "learning" factor is represented by the finding that students felt the computer and the online activities gave them control over their learning and helped them to learn faster, write better and become independent learners. Students in the technology - enhanced environment as depicted in this study ascribed their positive attitudes toward such an environment to these three factors.

Technology - based learning also seems to influence the improvement of linguistic skills (cononelos \& Oliva, 1993; Beauvois, 1994, $\&$ 1998). For example, the study conducted by Beauvois (1994) reference to the improvement of reading skills was made as $43 \%$ of the students reported that their reading skills had improved, and many of them also felt increased confidence in speaking. The researcher attributed this confidence to the increased amount of language use prompted by the technology - enhanced environment. In such an environment teacher dominance and speech is replaced by student interaction.

In her other study of (1998) entitled "E-talk: Attitudes and motivation in computer - assisted classroom discussion," Beauvois 
concludes that technology - based environment supports oral language production that lead to oral language development. This development was represented by the growth occurring in the speaking skills.

In another study by Glisan et al (1998) the researches found that videoconferencing technology helped to develop Spanish listening comprehension skills. They also found that students engaged in a more multi - modal approach to learning. The research reported that the role of the teacher as a moderator or a facilitator is a major variable to the success of technology - based instruction. The conclusion was that a technology environment based on constructivist principles may be ideal for enhancing learner attitude and motivation.

In a similar study by (Coverdale - Jones. 2001) on student perceptions about a videoconferencing project between students of German and native speakers in Germany, the sample cited two advantages for the use of technology : a) the ease and quickness of communication with a real person from the same age group, and b) the interactivity of the videoconferencing. Nevertheless, they perceived one important disadvantage because they also viewed videoconferencing as a reduced from of communication when compared to face - to - face live interaction.

On the other hand, some other researchers believe that the shift from classroom formal instruction to extending learning beyond the classroom and incorporating technical elements help develop communication skills as well as life skills. That in turn helps learners solve a lot of academic and professional problems. (Abdu Hameed, 2002 \& Alamer, 2003).

The most common - and in fact, nearly universal - teacher reported effect on students was an increase in motivation. Teachers and students are sometimes surprised at the level of technology - based accomplishments displayed by students who have shown much less initiative or ability with more conventional academic tasks. Teachers talked about motivation from a number of different perspectives. Some mentioned motivation with respect to working in a specific area, for example, a greater willingness to write or to work on computational skills. Others expressed this in terms of more general motivational effects such as student satisfaction with the computer - based environment and the immediate feedback provided by the computer and the sense of accomplishment and empowerment gained in working with technology. 
In consistence with this and in a more recent study conducted by Deborah Gill (2006) on "the effects of technology on second language learning," the researcher aimed at presenting preliminary findings regarding the implementation of technology in the foreign language classroom focusing on writing and surveying student perceptions toward online education. She concluded that technology is a powerful tool when used correctly. Its effect on language can be tremendousin all areas, from language skills (i.e., listening, speaking, reading and writing) to providing students with the opportunity to become more global and develop higher levels of thinking skills. Technology - infused language learning increased student confidence, motivation and learning. Moreover, as seen by the comments of the students(,) they felt the experience was fun, interesting and made then assume ownership of their learning.

\section{Experimental Studies:}

Positive effects have also been reported in the language classroom context due to the use of online activities in learning. A case study of an FSL seniors' secondary course integrating computer networking, Sannaoui \& Lapkin (1992) found that the use of technology in learning led to the development of independent learning in high school students. According to Sannaoui and Lapkin (1992) e-mail exchanges between high school students learning French and native speakers of French made them assume increased responsibility for their learning and broadened their understanding about the French Culture.

In an experimental study by Bauclose (2003), the effectiveness of video - based anchored instruction was proved to be an effective strategy not only for developing language skills but also for developing higher order thinking and problem solving skills. Thus the technology - based environment effect extends from developing language skills, to technical skills, and moves far beyond to develop thinking skills. As stressed by (Abdul Hameed, 2003; Osman, 2006 \& Renzoly and Prees 2006) the traditional instructional programs in general do not allow students the opportunity to express their potentialities as they are constrained by rules and regulations that hinder the characteristics of enrichment programs. On the other hand, when free control over learning through different technological techniques is given, learners become more creative, more motivated and more able to learn. 
In a study entitled "the use of ICT in developing reading and writing skills in children with hearing impairment by Bans and Abdul Hameed (2007), the researchers investigated the improvement of reading and writing skills of these children. Due to lack of communication between the instructor and such learners, poor cognitive development is expected as shown in most related literature. Through this experimental study the researchers have shared a new technology - based teaching methodology to develop reading and writing skills among children with hearing impairment. The major objective of the study was to determine the effectiveness of video clipping in developing reading and writing abilities of hearing impaired children.

The t-test comparison on the reading and writing test showed significant differences on the post writing test $(\mathrm{p} \leq 0.001)$ in favour of the experimental group learners, but no significant differences were found for the reading skills. Thus video - clipping (a technology - enhanced environment) proved to be an effective teaching method for developing writing even for hearing - impaired learners.

In an experimental study by Ozdener \& Esfer" from Marmar University in Turkey (2009) entitled" A comparative study on the use of information technologies in the development of students' ability to comprehend what they listen to and watch", the researchers tested the effects of computer - aided and video - aided instruction on developing learners' comprehension skills. An analysis of the student's post-test results showed a considerable difference in favour of the computer - aided method for achieving the target behaviors. Moreover, the researchers analyzed the participant's answers in a feedback form to determine how the students found the application, and found that $67 \%$ of experimental group one, 57\% of group two and $47 \%$ in group three thought that the time was adequate and between $80 \%$ to $90 \%$ in all three groups responded that they enjoyed the application and wanted to go ahead with it.

During PSLC's first four years, its interactive communication cluster studied interaction between students and a tutor (either human or computer) or, les frequently, two students interacting with each other. Most of the experimental manipulations and subsequent analyses focused on the cognitive content of interaction, in other words, the what and when instruction. Study results (reported July, 2010) investigating the effect of interaction, although somewhat mixed, have largely supported the 
hypothesis that focused interaction promotes cognitive aspects of learning such as attention to the most important knowledge components in a domain, deeper cognitive processing, and increased engagement with the content.

\section{Commentary on Previous Studies:}

All the studies surveyed seem to prove technology - enhanced teaching and learning to be an effective and interpretive educational method for improving student linguistic, technical and cognitive skills. (They) showed that using computer, video, e-mail exchanges and internet -based activities eases teachers' class management problems, increases students' and teachers' attention level, and enhances the learning and teaching effectiveness (Warshawer, 1996; Beauvois, 1998; Glisan et al, 1998; Coveradale - Jones, 2001 \& Gill, 2006).

Moreover, in many of these studies, a related technology effect stressed by many teachers was the enhancement of motivation (Warschaver , 1996), language skills (Cononelos \& Oliva, 1993; Beauvois, 1994 \& 1998), listening, reading and writing skills (Glisan et alp 1998 Gill, 2006; Baon and Abdul Hammed, 2007). in these studies the most common reported effect on students was an increase in motivation, self - esteem and self - confidence. This can be due to the sense of satisfaction they feel due to the increased competence they gain after mastering the technology based tasks and their awareness of the value placed upon technology in modern teaching. Another effect of technology cited by a great majority of these studies is the development of technical skills as participants become able to acquire an impressive level of skill. This in itself made them take pride in their accomplishment which may have led to more self-esteem and self-confidence.

Moreover, there was an increased inclination on the part of students to work cooperatively and to provide peer tutoring. Thus students take an active role rather than the passive role of recipient of information transmitted by a teacher or a textbook. Thus, technology allows students to be actively thinking about information, making choices, and executing skills typical in teacher - led lessons, in brief it promotes more interaction. Additionally, students find this interaction more enjoyable. 


\section{Sample:}

The population from which the sample was derived is first year female students enrolled in the Arabic department at Princess Nora University in Riyadh during the academic year 1430 / 1431 AH. The sample was selected according to the available classes and the instructor(')s willingness to participate. Table (1) shows the number of participants.

Table (1) The Number of Participants

\begin{tabular}{|c|c|c|c|c||}
\hline Group & $\begin{array}{c}\text { Initial } \\
\text { Number }\end{array}$ & Excluded & Participants & $\begin{array}{c}\text { Total } \\
\text { Number }\end{array}$ \\
\hline \hline Experimental & 35 & 7 & 28 & 28 \\
\hline Control & 35 & 6 & 29 & 29 \\
\hline & & & & 57 \\
\hline
\end{tabular}

The above table indicates the total number of learners and those who were excluded due to irregular attendance or lack of technical skills needed to deal with online learning.

\section{Instruments :}

Two instruments were used: an essay type test measuring writing (appendix 1) and a questionnaire (appendix2)

\section{Validity of the test:}

The test was submitted to a group of specialist juries and modifications were accordingly made.

\section{Reliability of the test:}

Inter-rater reliability was used with a rubric designed by the researcher. The rubric used a scale from 0 to 4 consisting of three dimensions : focus and organization, development of ideas and style and finally grammar and mechanics. Each dimension included four criteria. Two raters scored the test and the mean score was used.

\section{The Questionnaire :}

The questionnaire consisted of 35 items asking students who participated in the experiment to indicate whether they strongly agreed, disagreed or strongly disagreed. the items aimed at eliciting information 
about participants' perceptions in four categories : (a) the instructor's role and facilitative behavior in the technology - based environment, (b) the utility and benefits of the lab and he online learning environment, (c) the effect of the new experiment on increasing their interest and d) the effect of the new experiment on the student, motivation, self -confidence and enjoyment.

\section{Procedure :}

Before administering the experiment two orientation sessions were conducted with the two instructors who participated in both the experimental and the control groups. The first session focused on indicating the theoretical background of the study and the procedure that each had to follow.

The second session included a demonstration by the researcher for one of the tasks followed by a discussion as the researcher responded to all the questions posited by the participating teachers.

\section{Pre-testing :}

The writing test was administered to both groups before instruction began. The t-test for independent groups was used for both the experimental and the control groups. Results of the t-test are shown in table (2)

Table (2)

The t-values of the pre-test scores for both groups

\begin{tabular}{||c|c|c|c|c|c||}
\hline \hline Group & N & Mean & Std. & t-value & $\begin{array}{c}\text { Sig. (2- } \\
\text { tailed) }\end{array}$ \\
\hline \hline Experimental & 28 & 11.301 & 3.186 & 0.251 & 0.0804 \\
\hline Control & 29 & 1.0924 & 2.998 & & 0.040 \\
\hline
\end{tabular}

Table (2) shows that there are no statistically significant differences between the experimental and the control group students in the pre-test scores.

\section{Description of the study:}

The experiment took place during the first term of 1430/1431 AH and lasted for twelve weeks, two hours per weed with a total of twenty four hours. 
At the end of the first term both instruments were applied. The questionnaire was administered to the control group students only, while the post test was administered to both groups.

\section{Results and Discussion:}

A) Results related to the effect of computer - mediated activities: two types of t-test were used: $t$-test for independent samples with the aim of comparing the scores of the control and the experimental groups, paired sample t-test was also used to compare the pre-test and post-test mean scores of the experimental group.

Table (3) shows the results of the t-test independent samples.

Table (3)

The t-value for the post-test scores of both groups

\begin{tabular}{|c|c|c|c|c||}
\hline Group & N & Mean & Std. & t- sig (2-tailed) \\
\hline \hline Experimental & 28 & 77.1241 & 12.9986 & 3.372 \\
\hline Control & 29 & 66.3901 & 13.4020 & 0.001 \\
\hline
\end{tabular}

Result presented in table (3) show a statistically significant difference $(\mathrm{P}<0.001)$ between the post-test mean scores of the two groups in favour of the experimental group. Similar findings were reached by Gass; Mackey and Ross (2005), who found that technology - based labs help improve learning and enhance interaction significantly. This was later confirmed by Lin and Chin (2007) who concluded that the multimedia environment promotes language learning skills including reading and writing.

This can be attributed to the increased amount of interaction between learners as they read each other's postings and communicate in authentic situations. Tsinghong (2009) confirms that a communicative language teaching environment helps improve not only the listening skill but the four language skills of listening, speaking, reading and writing.

The paired samples t-test was used to compare the pre and posttest scores of the experimental group. Table (4) shows the t-value of this comparison which indicates that the students' post achievement is significantly higher than their achievement before using the technology based learning. 
Table (4)

The t-value for the pre - test and post - test

mean scores of the experimental group on the writing test

\begin{tabular}{|c|c|c|c|c|c|}
\hline Administration & $\begin{array}{c}\text { Mean } \\
\text { score }\end{array}$ & Std. & $\begin{array}{c}\text { Paired } \\
\text { Differences }\end{array}$ & t-value & Sig \\
\hline \hline Pre & 11.2634 & 3.1765 & Mean & Std. & \multirow{2}{*}{0.00} \\
\cline { 1 - 5 } Post & 13.4740 & 2.8720 & 2.2005 & $\begin{array}{c}2.802 .3 \\
4.8\end{array}$ & \\
\hline
\end{tabular}

The data shown in table (4) indicate significant differences $(\mathrm{P}<0.001)$ between the mean scores of the pro-test and post - test of the experimental group students on the writing skill. These differences are in favour of the post administration of the test. This indicates that the computer - mediated activities performed by the experimental group students were rich enough to improve their use of written expression.

This improvement in wiring due to training on technology enhanced learning could be attributed to two main factors: first, learners had the opportunity to view all the writings of their colleagues on the screen which exposed them to new idea, expressions and vocabulary which they could make use of in further writing assignments. This was confirmed in previous studies as (Cononelos \& Oliva , 1993; Warshcauer, 1996, \& Beauvois, 1998) ensured that the use of technology in language learning seems to influence the development of learners' linguistic skills. These researchers have reported an improvement in students' writing skill through the use of networked computers. According to Beauvois (1998) students in the networked writing project showed more fluidity of conversation, more use of complex sentences and more self - disclosure. She believes that the elimination of strong teacher dominance freed students to express themselves, resulting in a larger quantity and better quality of communication specifically the writing aspect of communication.

Second, students in the computer activities - mediated group had a stronger purpose represented in real communication while exchanging thoughts with their colleagues and not just to write in response to an activity assigned by the teacher. 


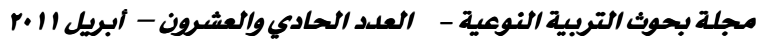

\section{B) Results Related to the learners' Perceptions:}

For the purpose of these results, data are reported in numbers and percentages of student response.

\section{- The teacher's role as facilitator:}

About $85 \%$ of the sample either agreed or strongly agreed that the teacher had a significant role in helping them to overcome difficulties with the activities. More than $85 \%$ of them agreed that the instructor facilitated problems related to computer use and that her presence during the lab classes increased learning.

Yet, a small percentage (14.90\%) did not seem to value the role of the instructor as a facilitator especially after the initial interference of the teacher. They were convinced that once they learned how to mange the activities, they can proceed on their own without interference of the teacher. According to them, the instructor was no longer necessary.

\section{Perceptions concerning the effect on learning:}

Nearly $74 \%$ of the sample felt that the activities had a positive effect on their learning (34\% strongly agreed and $40 \%$ agreed). They felt that learning through technology is better than traditional learning taking place in regular classes. Moreover, a great majority of the students $(70.8 \%$ agreed and a large part of them - 49\% - strongly agreed) felt an increased improvement in their writing and in communication skills as well. These perceptions of improvement in communication skills and writing skills are consistent with the findings of improved linguistic skills reached by Glisan et at (1998) in their study on teaching Spanish through distant education.

In spite of divided perceptions concerning this variable, nearly two - thirds of the sample surveyed (64.8\%) agreed that the value of the experience was highly enjoyable and interesting. Slightly more than half of the students expressed their willingness to take another course of computer and technology enhanced learning if they were allowed the opportunity.

In spite of the fact that nearly two - thirds of the students favoured the technology - enhanced instruction, more than third of the sample $(35.2 \%)$ expressed their wish to have traditional face - to - face instruction. 
The effect of computer-enhanced learning through the use of Asynchronous discussion $=$

\section{Perceptions Concerning effect on learner confidence:}

For a large majority of learners participating in the experience, $58.7 \%$ agreed they had gained confidence in their ability to complete the complex activities in the lab environment. They also expressed a growth in their technical skills as feeling with online activities intimidated them at the beginning but they gradually managed to deal with them easily and faster.

\section{Conclusions and pedagogical implications:}

In view of the results reached through the present research, the following implications for classroom activities design in a technology enhanced environment can be drawn.

The results of the experiment indicate that online activities and making use of the computer in learning and teaching is pedagogically important. Such an environment lends support to learning linguistic skills and adds enjoyment to participants. Thus, it is highly recommended to use more activities related to other subject - matters and other skills in view of the large majority that expressed the need for the presence of the teacher not only as a facilitator but as a participant in interaction as well synchronous online should be added and studied.

The findings - particularly those of the questionnaire - imply that the teacher's role in technology enhanced environment is crucial. The issue of teacher facilitation must also be addressed in technology - based instruction because of the negative perceptions of some of the students (a little more than one - third of the sample) about the instructor's role as a facilitator. This may imply that the instructor facilitation was still inadequate. Therefore, designing synchronous online learning that necessitates the presence of the teacher in web - based and online learning activities is also important. Moreover, instructors and faculties of education and would be teachers should be prepared to deal with the technology enhanced activities. Additionally, instructors working in such an environment mediated by technology need support and preparation to adopt new roles to help students move smoothly from traditional learning to technology - based learning.

For the development of professional skills an instructor must embrace new pedagogical skills as well as technical and managerial skills. Besides the facilitative role of the instructor with its skills, teachers must 
also acquire new skills such as negotiation of meaning with the learners. They need to be prepared to respond to the unpredictable questions of the students, which is different from the regular planned lesson of the traditional classroom setting.

Moreover, issues dealing with curriculum design must also be addressed. Within the technology enhanced environment structured activities and scaffolding activities that activate the learners' prior knowledge or work as advance organizers should be planned and sequenced within the curriculum to enable every student to participate positively. It was proved in other studies (Conrad, 1999) that beginning students in general and low achievers prefer to learn more from drill and tutorial programs than more able ones. This draws attention to the conflict that exists between structured learning that dissuades the development of the highly valued independent learning and the challenging technology - based environments that encourage learners to assume an active participatory role and take responsibility for their own learning. This issue should be taken into account when making curricular instructional design decisions for technology - based programs.

To conclude, more empirical and experimental studies should be conducted concerning the effect of different multimedia instruction on the development of specific skills . T)he perceptions of students about the modes of instruction and the relationship between these perceptions and students' actual achievements should be considered. 


\section{Reference :}

1. Beauvois, M. (1993). Conversations in slow motion: Computer - mediated communication in the foreign language classroom. The Canadian Modern language Review, 54 (2) , 198-217.

2. Beauvois, M. (1994). E-talk : Attitudes and motivation in computer - assisted classroom discussion. Computers and the Humanities, 28 (1), 177 - 190.

3. Beauvois, M. (1996). Personality types and megabytes; Students' attitude toward computer - mediated communication (CMC) in the language classroom. (ALICA Journal, 13 9203), 27-45.

4. Blythe, C. (1997) A constructivist approach to grammar: teaching teacher to teach aspect. The modern language Journal, 81 (1), 50-66.

5. Conard, D. (1999). The student view on effective practices in the college elementary and intermediate foreign language classroom. Foreign language Annals, 32 (4), 494 - 521.

6. Connelos, T. \& Oliva, M. (1993). Using computers networks to enhance foreign language / culture education. Foreign languages annals, 26(4), 527 533.

7. Coverdale - Jones, T. (2000). The use of video conferencing as a communication tool for language learning: issues and considerations. IALL Journal, 32 (1), $27-40$.

8. Drooks, J. \& Brooks, M. (1993). The case for constructivist classroom. Alexandria, VA: Association for supervision and curriculum Development.

9. Dwyer, D. (1996). A response to Duglas Noble: we're in this together. Educational Leadership, 54 (3), $24-27$.

10. Gass, S.; Mackey, A. \& Ross, L. (2005). Task - based interactions in classroom and laboratory settings. Language learning, 55 (4), 575 - 611.

11. Glisan, G.; Dudt, K- \& Home, M. (1998). Teaching Spanish through distance education: Implications of a pilot study. foreign language Annals, 31, 48 - 66.

12. Lebew, D. (1993). Constructivist values for instructional systems design: five principles toward a new mindset. Educational Technology Research and Development: ETR \& D , 41 (3), 104-116.

13. Lin, H. \& Chin, T. (2007). Reading authentic EFL text using visualization and advance organizers in a multimedia learning environment. Language learning and Technology, 11 (3), 83-106.

14. Mc Grath, B. (1998). Partners in learning: twelve ways technology changes the student - teacher relationship. Technological Horizon in Education, 25 (9), 58 -62 .

15. Noweczyk, R. (1998). Student perceptions of multimedia in the undergraduate classroom. International Journal of instructional Media, 25, 367 - 368. 
16. Salaberry, M. (2001). The use of technology for second language learning and teaching: a retrospective. The Modern Language Journal, 85 (1), 41 - 56.

17. Sanaoui, R. \& Lapkin, S. (1992). A case study of an FSL senior secondary course incorporating computer networking. The Canadian Modern Language Review, 43 (3), 524 - 552.

18. Schrum, J. \& Glisan, E. (2000). Teacher's Handbook: Contextualized language instruction. Boston, MA: Heink \& Heink.

19. Tsinghong, M. (2009). An empirical study on teaching listening in CLT. International Education Studies, 2 (2), 126 - 134.

20. Warshauer, M. (1996). Motivational aspects of using computers for writing and communication. In M. warschauer (Ed.) telcollaboration in foreign language learning: Proceedings of the Hawai'I symposium (technical Report PP. $29-$ 46). Honolulu: University of Hawai'I, Second language Teaching \& Curriculum Centre.

21. Wilson, V. (2000). Can thinking skills be taught? The Scottish council for Research in Education, Edinburgh, TH 36 ML.

المراجع العربية :

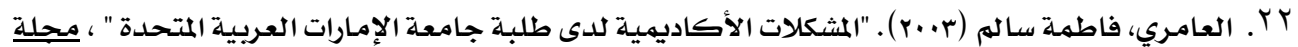

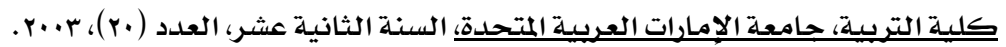

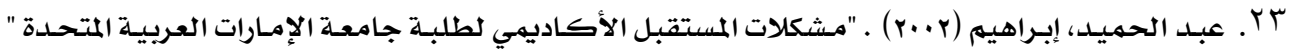

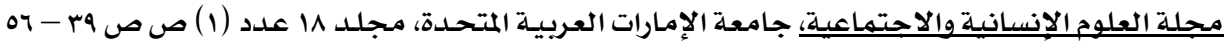

$$
\text { إبريل r.r. }
$$

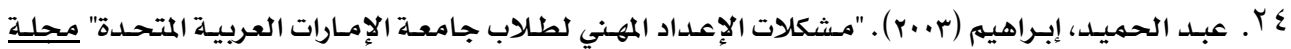

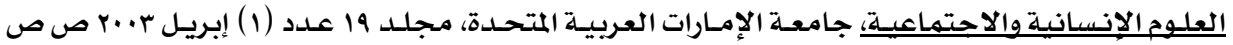
$. V V-r V$

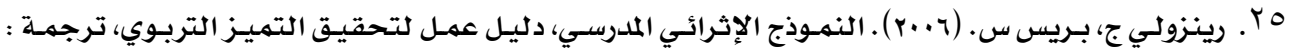

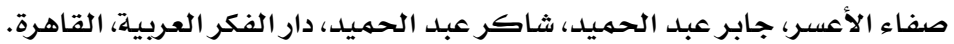

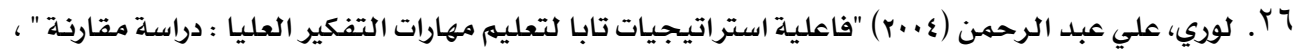

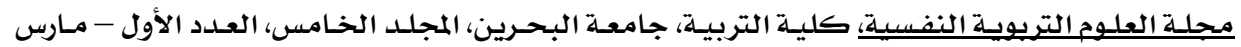
.va - -

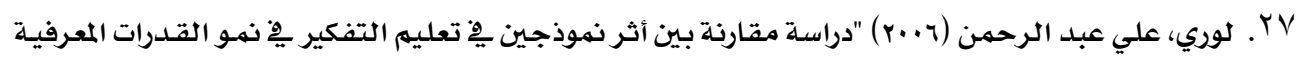
العليا لدى عينة من طالبات المرحلة الثانوية التجارية، مملكة البحرين"، مجلية العلوم التربويـة والنفسية.

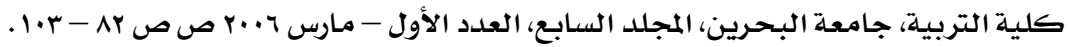




\section{Appendix (1)}

\section{The Writing Test}

A) Write an essay on each of the following topics :

1. The job you would like to have in the future indicating the reasons for your choice.

2. People you like and those you dislike showing why.

Write a letter to a pen pal explaining where and how you spent your last summer vacation. 


\section{Appendix -2-}

\section{Student Perceptions Questionnaire}

\begin{tabular}{|c|c|c|c|c|c|c|}
\hline A & The instructor's role & $\begin{array}{l}\begin{array}{l}\text { Strongly } \\
\text { disagree }\end{array} \\
\end{array}$ & disagree & agree & $\begin{array}{c}\begin{array}{c}\text { Strongly } \\
\text { agree }\end{array} \\
\end{array}$ & \begin{tabular}{|c|}
$\begin{array}{c}\text { No } \\
\text { response }\end{array}$ \\
\end{tabular} \\
\hline 1 & $\begin{array}{lr}\text { The } & \text { instructor } \\
\text { interacted } & \text { with me to } \\
\text { facilitate } & \text { language } \\
\text { problems } & \end{array}$ & & & & & \\
\hline 2 & $\begin{array}{|lr|}\text { During the computer- } \\
\text { mediated activities, the } \\
\text { instructor provided me } \\
\text { with } & \text { technical } \\
\text { assistance } & \\
\end{array}$ & & & & & \\
\hline 3 & $\begin{array}{l}\text { The presence of the } \\
\text { instructor during the lab } \\
\text { helped me learn more. }\end{array}$ & & & & & \\
\hline 4 & $\begin{array}{l}\text { Once I learned how) to } \\
\text { do the activities, I felt I } \\
\text { no longer needed the } \\
\text { instructor }\end{array}$ & & & & & \\
\hline 5 & $\begin{array}{l}\text { Discussions with the } \\
\text { instructor were really } \\
\text { necessary }\end{array}$ & & & & & \\
\hline 6 & $\begin{array}{l}\text { The instructor provided } \\
\text { clear instructions that } \\
\text { facilitated work to be } \\
\text { done }\end{array}$ & & & & & \\
\hline B & $\begin{array}{l}\text { The utility of the } \\
\text { activities concerning } \\
\text { learning }\end{array}$ & & & & & \\
\hline 7 & $\begin{array}{l}\text { I learned a lot from the } \\
\text { activities }\end{array}$ & & & & & \\
\hline 8 & $\begin{array}{l}\text { The information I } \\
\text { gained contributed to } \\
\text { my knowledge of the } \\
\text { Arabic language. }\end{array}$ & & & & & \\
\hline 9 & $\begin{array}{l}\text { My writing skills } \\
\text { improved due to the } \\
\text { activities I performed. }\end{array}$ & & & & & \\
\hline
\end{tabular}




\begin{tabular}{|c|c|c|c|c|c|c|}
\hline $\mathbf{A}$ & The instructor's role & $\begin{array}{l}\text { Strongly } \\
\text { disagree }\end{array}$ & disagree & agree & $\begin{array}{c}\text { Strongly } \\
\text { agree }\end{array}$ & $\begin{array}{c}\text { No } \\
\text { response }\end{array}$ \\
\hline 10 & $\begin{array}{l}\text { I feel that my other } \\
\text { skills in reading, } \\
\text { speaking and listening } \\
\text { have also improved. }\end{array}$ & & & & & \\
\hline 11 & $\begin{array}{l}\text { As time went on, I felt } \\
\text { like I managed to work } \\
\text { with the computer more } \\
\text { quickly }\end{array}$ & & & & & \\
\hline 12 & $\begin{array}{l}\text { I learned more language } \\
\text { skills than I usually do } \\
\text { in regular classes }\end{array}$ & & & & & \\
\hline 13 & $\begin{array}{l}\text { The activities drove me } \\
\text { to search for more } \\
\text { examples online. }\end{array}$ & & & & & \\
\hline 14 & $\begin{array}{l}\text { I put more time in this } \\
\text { class than in regular } \\
\text { ones, so it was more } \\
\text { time consuming }\end{array}$ & & & & & \\
\hline 15 & $\begin{array}{l}\text { My use of expressions } \\
\text { when wiring became } \\
\text { better and longer as a } \\
\text { result of the activities }\end{array}$ & & & & & \\
\hline $\mathrm{C}$ & $\begin{array}{l}\text { Perceptions Concerning } \\
\text { Interest in technology - } \\
\text { based environment }\end{array}$ & & & & & \\
\hline 16 & $\begin{array}{l}\text { I greatly enjoyed the } \\
\text { activities }\end{array}$ & & & & & \\
\hline 17 & $\begin{array}{l}\text { The learning experience } \\
\text { in the computer lab } \\
\text { made the course more } \\
\text { interesting }\end{array}$ & & & & & \\
\hline 18 & $\begin{array}{l}\text { I enjoyed the } \\
\text { discussions conducted } \\
\text { by the instructor }\end{array}$ & & & & & \\
\hline & $\begin{array}{l}\text { If given a choice } \\
\text { between a regular class } \\
\text { and a computer- } \\
\text { mediated class, I would } \\
\text { choose the latter. }\end{array}$ & & & & & \\
\hline
\end{tabular}




\begin{tabular}{|c|c|c|c|c|c|c|}
\hline A & The instructor's role & $\begin{array}{l}\text { Strongly } \\
\text { disagree }\end{array}$ & disagree & agree & $\begin{array}{c}\text { Strongly } \\
\text { agree }\end{array}$ & $\begin{array}{c}\text { No } \\
\text { response }\end{array}$ \\
\hline 19 & $\begin{array}{l}\text { The tasks I performed } \\
\text { were relevant to real life } \\
\text { needs in the Arabic } \\
\text { language. }\end{array}$ & & & & & \\
\hline 20 & $\begin{array}{l}\text { The tasks I performed } \\
\text { were relevant to real life } \\
\text { needs in the Arabic } \\
\text { language. }\end{array}$ & & & & & \\
\hline 21 & \begin{tabular}{|lr} 
I enjoyed doing \\
computer-based writing \\
assignments & more than \\
ones with & traditional \\
writing. &
\end{tabular} & & & & & \\
\hline 22 & $\begin{array}{l}\text { The whole experience } \\
\text { was enjoyable }\end{array}$ & & & & & \\
\hline 23 & $\begin{array}{l}\text { I liked interaction with } \\
\text { the teacher. }\end{array}$ & & & & & \\
\hline 24 & \begin{tabular}{|lcc} 
Interactions with my \\
colleagues made & me \\
like writing more. &
\end{tabular} & & & & & \\
\hline 24 & \begin{tabular}{|lcc} 
Interactions with my \\
colleagues made \\
like writing more.
\end{tabular} & & & & & \\
\hline 25 & $\begin{array}{l}\text { If I get a chance to } \\
\text { pursue another similar } \\
\text { course, I would greatly } \\
\text { prefer that. }\end{array}$ & & & & & \\
\hline 26 & $\begin{array}{l}\text { I learned how to be } \\
\text { resourceful in finding } \\
\text { the meaning of difficult } \\
\text { items. }\end{array}$ & & & & & \\
\hline 27 & $\begin{array}{l}\text { I gained confidence in } \\
\text { my ability to do the } \\
\text { Arabic language } \\
\text { activities. }\end{array}$ & & & & & \\
\hline 28 & $\begin{array}{l}\text { I gained confidence in } \\
\text { my ability to work } \\
\text { independently }\end{array}$ & & & & & \\
\hline & I learned how to work & & & & & \\
\hline
\end{tabular}


The effect of computer-enhanced learning through the use of Asynchronous discussion

\begin{tabular}{|c|c|c|c|c|c|c|}
\hline A & The instructor's role & $\begin{array}{l}\text { Strongly } \\
\text { disagree }\end{array}$ & disagree & agree & $\begin{array}{l}\text { Strongly } \\
\text { agree }\end{array}$ & \begin{tabular}{|c|} 
No \\
response \\
\end{tabular} \\
\hline & $\begin{array}{l}\text { out difficult points on } \\
\text { my own. }\end{array}$ & & & & & \\
\hline 30 & $\begin{array}{l}\text { I was initially frustrated } \\
\text { by the numerous } \\
\text { activities I had to do. }\end{array}$ & & & & & \\
\hline 31 & $\begin{array}{l}\text { I was initially frustrated } \\
\text { by having to work on } \\
\text { my own. }\end{array}$ & & & & & \\
\hline 32 & $\begin{array}{l}\text { Taking the computer- } \\
\text { mediated class } \\
\text { detrimental was } \\
\text { performance. }\end{array}$ & & & & & \\
\hline 33 & $\begin{array}{|lc|}\text { My } & \text { frustration } \\
\text { gradually vanished }\end{array}$ & & & & & \\
\hline 34 & $\begin{array}{l}\text { I grew more eager to do } \\
\text { similar activities. }\end{array}$ & & & & & \\
\hline 35 & $\begin{array}{l}\text { The experience greatly } \\
\text { motivated me to do } \\
\text { extra activities. }\end{array}$ & & & & & \\
\hline
\end{tabular}

